\title{
DAMPAK PENGUMUMAN PENURUNAN HARGA BBM TERHADAP ABNORMAL RETURN PADA PERUSAHAAN YANG TERGABUNG DALAM IDX30
}

\author{
Ni Komang Mega Sri Utami ${ }^{1}$ \\ Ida Bagus Anom Purbawangsa ${ }^{2}$ \\ 1,2Jurusan Manajemen Fakultas Ekonomi dan Bisnis Universitas Udayana (Unud), \\ Bali, Indonesia \\ email :komangmegasari475@gmail.com
}

\begin{abstract}
ABSTRAK
Salah satu informasi yang sangat berpengaruh terhadap perekonomian Indonesia adalah kebijakan pemerintah untuk menurunkan harga Bahan Bakar Minyak (BBM). Studi ini bertujuan untuk mengetahui pengumuman penurunan harga BBM dapat menciptakan perolehan Abnormal return yang signifikan sebelum, saat dan sesudah pengumuman penurunan harga BBM tanggal 31 januari 2020. Penelitian ini dilakukan pada perusahaan yang masuk dalam IDX30 dengan menggunakan metode sensus mendapatkan jumlah sampel sebanyak 15 perusahaan. Periode jendela peristiwa yang digunakan yaitu selama 11 hari (lima hari sebelum, hari h, lima hari sesudah) dengan teknik analisis data one sample t-test untuk menguji signifikansi Abnormal return sebelum, saat dan sesudah peristiwa. Berdasarkan hasil uji one sample t-test menunjukkan hasil bahwa tidak terdapatnya Abnormal return yang signifikan selama periode peristiwa sehingga tidak terjadi reaksi pasar disekitaran periode pengumuman penurunan harga BBM

Kata kunci: Pengumuman penurunan harga BBM, Abnormal return, event study.
\end{abstract}

\begin{abstract}
One of the information that greatly influences the Indonesian economy is the government's policy to reduce the price of fuel oil (BBM). This study aims to determine that the announcement of a reduction in fuel prices can create a significant Abnormal return before, during and after the announcement of a reduction in fuel prices on January 31, 2020. This research was conducted on companies that are included in the IDX30 using the census method to get a total sample of 15 companies. The event window period used is 11 days (five days before, the day, five days after) with the one sample t-test data analysis technique to test the significance of Abnormal returns before, during and after the event. Based on the results of the one sample t-test, it shows that there was no significant Abnormal return during the event period so that there was no market reaction around the announcement period of the reduction in fuel prices.
\end{abstract}

Keywords: Announcement of reduction in fuel prices, Abnormal returns, event study. 


\section{PENDAHULUAN}

Pasar modal dapat dikatakan sebagai pasar untuk memperjualbelikan instrument keuangan jangka panjang seperti saham, obligasi dan reksa dana, sedangkan tempat di mana terjadinya jual beli sekuritas disebut dengan bursa efek. Keberadaan pasar modal disuatu negara bisa menjadi acuan untuk melihat tentang bagaimana kegairahan atau dinamisnya bisnis negara yang bersangkutan dalam menggerakkan berbagai kebijakan ekonominya seperti kebijakan fiskal dan moneter (Syahputri, 2018).

Pasar modal juga dapat bertindak sebagai lembaga perantara. Fungsi tersebut menunjukkan pentingnya peran pasar modal dalam mendukung perekonomian, karena pasar modal dapat menghubungkan pihak yang membutuhkan dana dengan pihak yang memiliki kelebihan dana. Selain itu, pasar modal dapat mendorong terciptanya alokasi modal yang efisien, karena dengan adanya pasar modal tersebut kelebihan modal (investor) dapat memilih opsi investasi yang memberikan return yang optimal. Investasi merupakan akumulasi dari simpanan yang dimiliki oleh seseorang digunakan untuk memperoleh asset yang lebih produktif (real asset maupun financial asset) daripada tabungan (Ardiana, 2016:10).

Investor sebagai pihak yang menginvestasikan dananya pada perusahaan perlu mencari berbagai informasi yang berkaitan dengan perusahaan dan menilainya sebagai bahan pertimbangan sebelum mempercayakan dananya dikelola oleh perusahaan, agar dana yang ditanamkan di perusahaan benar-benar menguntungkan bagi investor. Peristiwa yang terjadi di lingkungan pasar modal, baik peristiwa ekonomi dan non ekonomi memiliki kandungan informasi yang dapat mempengaruhi pasar modal (Dinar \& Kiryanto, 2015). Peristiwa yang bersifat mikro ekonomi (laporan kinerja perusahaan, pembagian deviden, Rapat Umum Pemegang Saham, dan lainnya) dan makro ekonomi (kebijakan moneter fiskal, Peraturan Pemerintah dan sebagainya). Peristiwa politik merupakan salah satu informasi yang diserap oleh para pelaku pasar modal dan digunakan untuk memperoleh keuntungan yang diharapkan di masa yang akan dating (Nabila \& Khairunnisa, 2015)

Salah satu informasi yang sangat berpengaruh terhadap perekonomian Indonesia adalah kebijakan pemerintah untuk menurunkan harga Bahan Bakar Minyak (BBM), sebagai komoditas yang berperan penting dalam kegiatan perekonomian Bahan Bakar Minyak (BBM) yang tentunya akan berdampak pada harga saham Indonesia. Pada tanggal 31 Januari 2020 diterbitkannya pengumuman resmi penurunan harga bahan bakar minyak (BBM) dari Rp. 9.200 menjadi Rp. 9.000. Peristiwa penurunan harga Bahan Bakar Minyak (BBM) memberikan dampak positif pada harga saham di Bursa Efek Indonesia, khususnya perusahaan transportasi yang sangat membutuhkan Bahan Bakar Minyak dalam mendukung operasionalnya (Anisah et al., 2017). Risiko investasi di pasar modal pada prinsipnya berkaitan dengan volatilitas harga saham, dimana naik turunnya harga saham dipengaruhi oleh informasi yang tersedia. Suatu informasi akan menyebabkan harga saham naik jika informasi tersebut memberikan berita baik (good news) dan informasi ini akan menyebabkan harga saham turun jika informasi tersebut membawa berita buruk (bad news). Reaksi 
pasar yang positif dianggap sebagai good news tercermin dari adanya Abnormal return yang positif serta terjadi perubahan volume perdagangan disekitar tanggal pengumuman penurunan harga Bahan Bakar Minyak (BBM), sedangkan kenaikan harga Bahan Bakar Minyak (BBM) dianggap sebagai suatu bad news oleh pasar tentunya akan memperoleh reaksi yang negatif dari pasar.

Abnormal return merupakan kelebihan dari return yang sesungguhnya terjadi terhadap return normal. Return normal merupakan return ekspektasian (return yang diharapkan oleh investor) (Hartono, 2017:667). Selisih dari returntersebut dapat berupa selisih positif maupun selisih negatif. Jika Abnormal return positif berarti return yang sesungguhnya lebih besar dari return yang diharapkan oleh investor, sedangkan jika Abnormal return negative berarti return yang sesungguhnya lebih kecil dari return yang diharapkan oleh investor.

Beberapa penelitian yang telah dilakukan sebelumnya mengenai Abnormal return yang muncul pada reaksi pasar terhadap pengumuman harga Bahan Bakar Minyak (BBM) memiliki beberapa temuan. Penelitian yang dilakukan oleh Ningsih \& Cahyaningdyah (2014) mendapatkan hasil bahwa tidak terdapat perbedaan yang signifikan antara Abnormal return sebelum dan sesudah peristiwa kenaikan harga BBM pada 22 Juni 2013 yang menunjukkan bahwa pengumuman kenaikan harga BBM tanggal 22 Juni 2013 tidak menimbulkan Abnormal return. (Gursida \& Indrayono, 2019) menemukan bahwa dampak pengumuman kebijakan tidak menimbulkan respons pasar yang signifikan, dimana mayoritas sektor ekonomi secara konsisten bereaksi negatif.

Hasil yang didapat (Anita \& Veronica, 2016) bahwa perubahan harga bahan bakar minyak berdampak negatif signifikan terhadap return saham. (Ardani, 2019) mendapat hasil penelitian yang menunjukan bahwa, tidak terdapat perbedaan Abnormal return dan volume perdagangan saham sebelum dan sesudah kenaikan harga BBM. Andarini (2016) menyimpulkan bahwa tidak terdapat reaksi pasar modal terhadap peristiwa pengumuman kenaikan BBM yang ditunjukkan dengan tidak adanya perbedaan yang signifikan pada AAR dan ATVA sebelum dan sesudah pengumuman. Kharisma \& Jogiyanto (2016) menyimpulkan bahwa peristiwa perubahan harga minyak tidak memiliki dampak yang berbeda yang terlihat dari rata-rata Abnormal return saham.

Penelitain dari (Dordi \& Weber, 2019) menemukan bahwa pengumuman divestasi menurunkan harga saham perusahaan bahan bakar fosil, sehingga 'divestor' dapat mempengaruhi harga saham perusahaan target mereka. (Dananjaya, 2020) menemukan bahwa Penetapan Perpres Poin 55 Tahun 2019 terdapat perbedaan rata-rata Abnormal return negatif sebelum dan sesudah peristiwa. (Liu et al., 2019) menemukan bahwa reaksi terhadap pengumuman keputusan pemeliharaan, harga minyak tidak mengalami perubahan yang jelas selama periode sampel. Nur et al., (2019) hasil penelitiannya menunjukkan pengujian uji beda rata-rata Abnormal return saham sebelum dan sesudah kejadian menunjukkan hasil yang tidak signifikan. (Chandra, 2013) menemukan bahwa terdapat Abnormal return negatif yang signifikan sebelum pengumuman kenaikan harga BBM dan terdapat Abnormal return yang positif setelah pengumuman kenaikan harga BBM. 
Hasil penelitian yang telah dipaparkan sebelumnya berbeda dengan beberapa penelitian yang telah dilakukan (Rosita Dewi et al., 2017) mendapatkan hasil analisis terdapat reaksi pasar positif atas pengumuman paket kebijakan ekonomi $\mathrm{X}$ dan terdapat perbedaan reaksi pasar antara sektor usaha yang diuntungkan dengan sektor usaha lainnya. (Saputra et al., 2017) hasil yang diperoleh menunjukkan bahwa berdasarkan pengujian hipotesis tidak terjadi reaksi pasar di sekitar peristiwa kenaikan harga BBM yang terlihat dari tidak terdapatnya Abnormal return positif yang signifikan. Penelitian yang dilakukan ((Febriyanti \& Rahyuda, 2016)menemukan bahwa pasar bereaksi positif sebelum dan sesudah peristiwa pengumuman kenaikan harga BBM dengan adanya perbedaan Abnormal return dan trading volume activity sedangkan pada sebelum dan sesudah pengumuman penurunan harga BBM pasar bereaksi negative yang menujukkan bahwa tidak terdapat perbedaan Abnormal return dan trading volume activity. (K \& P, 2018) menyimpulkan bahwa Pengumuman dividen 6 perusahaan di Muscat securities market berpengaruh positif signifikan terhadap harga saham perusahaan.

Dedunu (2018) Pengumuman Dividen tidak mengarah pada reaksi pasar positif atau negatif terhadap Harga Pasar yang tidak mendukung teori pensinyalan dan semua temuan menerima hipotesis nol sesuai dengan hasil analisis. Handoko (2016) Hasil dari penelitian ini adalah tidak terdapat perbedaan Abnormal return yang signifikan sebelum dan sesudah dividen diumumkan. (Agustina et al., 2018) menemukan hasil bahwa terdapat perbedaan rata-rata return saham, ratarata Abnormal return saham, dan volume perdagangan saham sebelum dan sesudah pengumuman pengampunan pajak. Choriliyah et al., (2016) mendapatkan hasil bahwa pasar modal bereaksi positif signifikan terhdap peristiwa pengumuman penurunan BBM tanggal 1 April 2016. (Ngoc \& Cuong, 2016) melakukan penelitian tentang dampak pengumuman dividen terhadap return saham menyimpulkan bahwa pengumuman dividen berpengaruh positif terhadap return saham di sekitar tanggal pengumuman. (Anggraini, 2017) menyimpulkan bahwa hasil penelitian menunjukkan reaksi pasar yang positif, terlihat dari Abnormal return positif dan TVA yang signifikan, pada saat pengumuman kebijakan holding.

Hasil penelitian dari (Putri et al., 2020) mendapatkan hasil penelitian menunjukkan Abnormal return yang positif signifikan terjadi di sekitar Pemilu 2019. Liogu \& Saerang (2015) hasil penelitiannya menunjukkan bahwa pasar bereaksi terhadap Pengumuman Kenaikan Harga BBM atas Saham LQ45 pada Tanggal 1 November 2014 dengan adanya Abnormal Return yang signifikan. (Prasetyo et al., 2020) menemukan bahwa peristiwa pengumuman kewajiban pasar domestik atas harga batubara memiliki kandungan informasi yang menyebabkan pasar modal Indonesia bereaksi terhadap peristiwa tersebut. (Asmas, 2018)menemukan perbedaan yang positif signifikan antara Abnormal return (AR) dan Trading Volume Activity (TVA) dengan pengumuman peristiwa sebelum dan sesudah penurunan harga bahan bakar. Febriyanti\& Rahyuda (2016) menemukan bahwa pasar bereaksi positif dengan adanya perbedaan Abnormal return dan trading volume activity sebelum dan sesudah peristiwa pengumuman kenaikan harga BBM sedangkan pada pengumuman penurunan 
harga BBM pasar bereaksi negative yang menujukkan bahwa tidak terdapat perbedaan Abnormal return dan trading volume activity sebelum dan sesudah pengumuman. Choriliyah et al., (2016) mendapatkan hasil bahwa pasar modal bereaksi positif signifikan terhdap peristiwa pengumuman penurunan BBM tanggal 1 April 2016. Liogu \& Saerang (2015) hasil penelitiannya menunjukkan bahwa pasar bereaksi terhadap Pengumuman Kenaikan Harga BBM atas Saham LQ45 pada Tanggal 1 November 2014 dengan hasil Abnormal Return yang signifikan, Trading Volume Activity yang signifikan dan Kapitalisasi Pasar yang signifikan. Penelitian sebelumnya menunjukkan adanya research gap dan membuka peluang untuk diteliti kembali. Berdasarkan uraian tersebut, maka hipotesis dalam penelitian ini dapat dirumuskan sebagai berikut:

$\mathrm{H}_{1}$ : Pengumuman penurunan harga BBM dapat menciptakan perolehan Abnormal return positif yang signifikan sebelum, saat dan sesudah pengumuman penurunan harga BBM tanggal 31 januari 2020

Pasar yang efisien adalah pasar dimana harga semua sekuritas sudah dapat mencerminkan semua informasi yang tersedia. Suatu pasar bereaksi terhadap suatu informasi untuk mencapai harga keseimbangan yang baru merupakan hal yang penting, jika pasar bereaksi dengan cepat dan akurat untuk mencapai harga keseimbangan baru yang sepenuhnya mencerminkan informasi yang tersedia, maka kondisi pasar seperti ini disebut dengan pasar efisien (Hartono, 2017:605).

Menurut Fama (1970) dalam (Hartono, 2017:606) mengklasifikasikan tiga macam bentuk utamadari efisiensi pasar berdasarkan ketiga macam bentuk informasi, yaitu informasi masa lalu, informasi sekarang yang sedang dipublikas ikan dan informasi privat sebagai berikut.

Efisiensi dalam bentuk lemah (weak form) pasar dikatakan efisien dalam bentuk lemah (weak form) jika harga-harga dari sekuritas tercermin secara penuh (fully reflect) informasi masa lalu. Informasi masa lalu ini merupakan informasi yang sudah terjadi. Bentuk efisiensi pasar secara lemah ini berkaitan dengan teori langkah acak (random walk theory) yang menyatakan bahwa data masa lalu tidak berhubungan dengan nilai sekarang. Jika pasar efisien secara bentuk lemah, maka nilai-nilai masa lalu tidak dapat digunakan untuk memprediksi harga sekarang. Ini berarti bahwa untuk pasar yang efisien bentuk lemah, investor tidak dapat menggunakan informasi masa lalu untuk mendapatkan keuntungan yang taknormal.

Efisiensi dalam bentuk setengah kuat (semi strong) pasar dikatakan efisien setengah kuat (semi strong form) jika harga- harga sekuritas secara penuh mencerminkan (fully reflect) semua informasi yang dipublikasikan (all publicly available information) termasuk informasi yang berada di laporan-laporan keuangan perusahaan emiten. Jika pasar efisien dalam bentuk setengah kuat, maka tidak ada investor atau grup dari investor yang dapat menggunakan informasi yang dipublikasikan untuk mendapatkan keuntungan taknormal dalam jangka waktu yang lama.

Informasi yang dipublikasikan yang hanya mempengaruhi harga sekuritas dari perusahaan yang mempublikasikan informasi tersebut. Informasi yang dipublikasikan ini merupakan informasi dalam bentuk pengumuman oleh 
perusahaan emiten. Informasi ini umumnya berhubungan dengan peristiwa yang terjadi perusahaan emiten (corporate event). Contoh dari informasi yang dipublikasikan ini misalnya adalah pengumuman laba, pengumuman pembagian dividen, pengumuman pengembangan produk baru, pengumuman merjer dan akuisisi, pengumuman perubahan metode akuntansi, pengumuman pergantian pemimpin perusahaan dan lain sebagainya.

Informasi yang dipublikasikan yang mempengaruhi harga-harga sekuritas sejumlah perusahaan. Informasi yang dipublikasikan ini dapat berupa peraturan pemerintah atau peraturan dari regulator yang hanya berdampak pada harga-harga sekuritas perusahaan-perusahaan yang terkena regulasi tersebut. Contoh dari informasi ini misalnya adalah regulasi untuk meningkatkan kebutuhan cadangan (reseroed requirement) yang harus dipenuhi oleh semua bank-bank. Informasi ini mempengaruhi secara langsung harga sekuritas tidak hanya sebuah bank saja, tetapi mungkin semua emiten didalam industri perbankan.

Informasi yang dipublikasikan yang mempengaruhi harga-harga sekuritas semua perusahaan yang terdaftar di pasar saham. Informasi inidapat berupa peraturan pemerintah atau peraturan dari regulator yang berdampak ke semua perusahaan emiten. Contoh dari regulasi ini adalah peraturan akuntansi untuk mencantumkan laporan aliran kas yang harus dilakukan oleh semua perusahaan. Regulasi ini akan mempunyai dampak keharga sekuritas tidak hanya untuk sebuah perusahaansaja atau perusahaan-perusahaan di suatu industri, tetapi mungkin berdampak langsung pada semua perusahaan.

Efisiensi dalam bentuk kuat (strong form) Pasar dikatakan efisien dalam bentuk kuat (strong form) jika harga- harga sekuritas secara penuh mencerminkan (fully reflect) semua informasi yang tersedia termasuk informasi yang privat. Jika pasar efisien dalam bentuk ini, maka tidak ada individual investor atau grup dari investor yang dapat memperoleh keuntungan taknormal (Abnormal return) karena mempunyai informasi privat.

Studi peristiwa (event study) merupakan studi yang mempelajari reaksi pasar terhadap suatu peristiwa yang informasinya dipublikasikan sebagai suatu pengumuman. Event study dapat digunakan untuk menguji kandungan informasi dari suatu pengumuman dan dapat juga digunakan untuk menguji efisiensi pasar bentuk setengah kuat. Pengujian kandungan informasi hanya menguji reaksi pasar, tetapi tidak menguji seberapa cepat pasar itu bereaksi. Pasar dikatakan efisien bentuk setengah kuat jika investor bereaksi dengan cepat untuk menyerap Abnormal return untuk menuju ke harga keseimbangan yang baru (Megawati et al. 2015). Kandungan informasi dapat berupa berita baik (good news) atau berita buruk (bad news). Peristiwa yang menjadi fokus event study (studi peristiwa) dapat dikelompokkan ke dalam Studi peristiwa konvensional mempelajari respons pasar terhadap peristiwaperistiwa yang seringkali terjadi dan diumumkan secara terbuka oleh emiten di pasar modal. Beberapa contoh studi peristiwa konvensional, antara lain: pembayaran dividen, pengumuman laba, merger dan akuisisi, dan bentuk sejenis lainnya, Studi peristiwa kluster mempelajari respons pasar terhadap peristiwa yang diumumkan secara terbuka yang terjadi pada waktu yang sama dan berdampak pada sekelompok perusahaan tertentu. Contoh peristiwa kluster adalah pengumuman pemerintah yang 
membuat regulasi pada industri tertentu sehingga diperkirakan berdampak pada aliran kas perusahaan dalam industri yang bersangkutan. dan Studi peristiwa tak terduga merupakan varian dari studi peristiwa kluster (Tandelilin, 2010: 566-569).

Penelitian tentang peristiwa tak terduga relatif belum banyak dilakukan, selain karena sifat peristiwa sangat jarang terjadi, tidak semua peristiwa tak terduga relevan dengan studi peristiwa terkait dengan pasar modal. Contoh penelitian tipe ini pernah dilakukan Hill \& Schneeweis (1983) yang meneliti dampak kebocoran nuklir Three Mile Island terhadap return tak normal perusahaan utilitas bertenaga nuklir dan non-nuklir. Studi peristiwa tidak terduga juga pernah dilakukan di Indonesia oleh Asri \& Arief (1998) yang meneliti respons pasar terhadap peristiwa kerusuhan 27 Juli 1996. Studi peristiwa berurutan juga merupakan varian dari studi peristiwa kluster. Studi ini mempelajari respon pasar terhadap serangkaian peristiwa-peristiwa yang terjadi secara berurutan dalam situasi ketidakpastian yang tinggi. Dalam hal ini, kecepatan dan ketepatan informasi menjadi kunci dari respon pasar.

Menurut Hartono (2017: 283) return merupakan hasil yang diperoleh dari investasi. Return dapat berupa return realisasian yang sudah terjadi atau return ekspektasian yang belum terjadi tetapi yang diharapkan akan terjadi dimasa mendatang.

Return Realisasian (realized return) merupakan return yang telah terjadi. Return realisasian dihitung menggunakan data historis. Return realisasian penting karena digunakan sebagai salah satu pengukur kinerja dari perusahaan. Return realisasian atau return histori ini juga berguna sebagai dasar penentuan return ekspektasian (expected return) dan risiko dimasa datang. Beberapa pengukuran return realisasian yang banyak digunakan adalah return total (total return), relatif return (return relative), kumulatif return (return cumulative) dan return disesuaian (adjusted return).

Return Ekspektasian (expected return) adalah return yang diharapkan akan diperoleh oleh Investor di masa mendatang. Mengestimasi return ekspektasi dapat dilakukan dengan menggunakan tiga model yakni Mean adjusted model beranggapan bahwa return ekspektasi bernilai konstan yang artinya sama dengan rata-rata Actual return. Pada model ini, return ekspektasi suatu saham pada periode tertentu diperoleh melalui pembagian Actual return saham tersebut dengan lamanya periode estimasi. Market model yaitu perhitungan return harapan dengan model ini dilakukan melalui dua tahapan, yaitu membentuk model ekspektasi dengan menggunakan data realisasi selama periode estimasi return. Kemudian menggunakan model ekspektasi ini untuk mengestimasi return ekspektasi pada periode jendela. Market adjusted model yaitu model ini beranggapan bahwa penduga terbaik dalam mengestimasi return suatu saham adalah return index pasar pada saat itu. Model ini tidak perlu menggunakan periode estimasi untuk membentuk model estimasi karena return saham yang diestimasi adalah sama dengan return index pasar (Hartono, 2017: 668).

Abnormal return merupakan selisih antara return yang diharapkan dengan return yang didapatkan. Selisih return akan positif jika return yang didapatkan lebih besar dari return yang diharapkan atau return yang 
dihitung. Sebaliknya Returnakan negatif jika return yang didapat lebih kecil dari return yang diharapkan atau return yang dihitung. Abnormal return dapat terjadi karena adanya kejadian-kejadian tertentu, misalnya hari libur nasional, awal bulan, suasana politik yang tidak menentu, pembagian dividen, stock split, right issue, penawaran perdana saham, dan lain-lain. Studi peristiwa menganalisis return tidak normal (Abnormal return) dari sekuritas yang mungkin terjadi di sekitar pengumuman dari suatu peristiwa. Handoko (2016) Abnormal return menggambarkan reaksi pemegang saham terkait suatu peristiwa yang merupakan return di luar pengharapan yang diperoleh investor atas suatu investasi yang dilakukan.

Berdasarkan rumusan masalah dan kajian pustaka yang telah diuraikan sebelumnya, kerangka konseptual penelitian dapat dijabarkan pada Gambar 1.

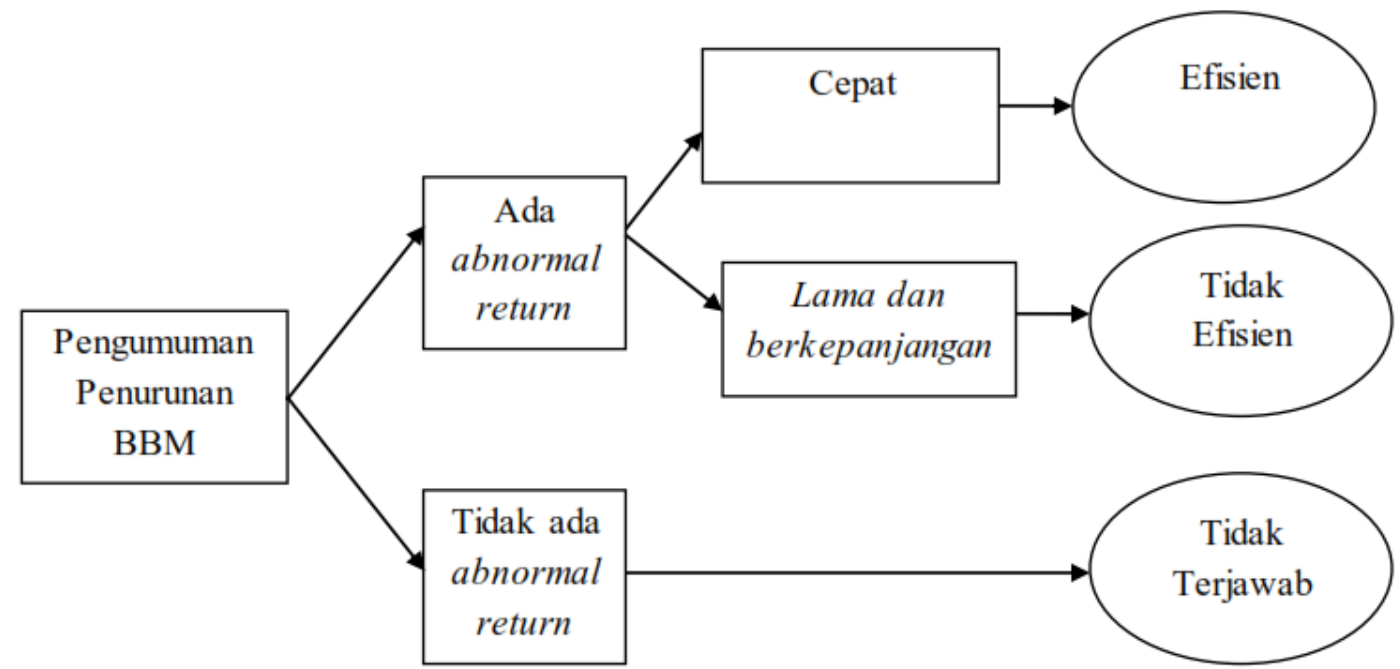

Gambar 1. Kerangka Konsep Penelitian Efisiensi Pasar Secara Informasi Sumber: Hartono (2017:647)

\section{METODE PENELITIAN}

Penelitian ini termasuk dalam kategori event study yang merupakan studi untuk mempelajari reaksi pasar terhadap suatu peristiwa yang informasinya dipublikasikan sebagai suatu pengumuman. Apabila pasar bereaksi, maka pengumuman dikatakan mengandung informasi. Periode pengamatan dilakukan selama 11 hari yang dimana lima hari sebelum, hari $\mathrm{h}$, dan lima hari setelah pengumuman penurunan harga bahan bakar minyak (BBM). Penelitian ini menggunakan metode market adjusted model untuk mengestimasi expected return. Populasi yang digunakan dalam penelitian ini adalah perusahaan yang konsisten masuk dalam IDX30 dari tahun 2012 sampai dengan periode Januari 2020 yaitu sebanyak 15 perusahaan. Metode yang digunakan untuk penentuan sampel adalah metode sensus sehingga jumlah sampel sama dengan jumlah anggota populasi penelitian. Sampel dalam penelitian dapat dilihat pada Tabel 1. sebagai berikut. 
Tabel l.

Daftar Perusahaan IDX30 Yang Menjadi Sampel Penelitian

\begin{tabular}{ccc}
\hline No. & Kode Saham & Nama Emiten \\
\hline 1 & ADRO & Adaro Energy Tbk. \\
2 & ASII & Astra International Tbk. \\
3 & BBCA & Bank Central Asia Tbk. \\
4 & BBNI & Bank Negara Indonesia (Persero) Tbk. \\
5 & BBRI & Bank Rakyat Indonesia (Persero) Tbk. \\
6 & BMRI & Bank Mandiri (Persero) Tbk. \\
7 & GGRM & Gudang Garam Tbk. \\
8 & INDF & Indofood Sukses Makmur Tbk. \\
9 & INTP & Indocement Tunggal Prakarsa Tbk. \\
10 & KLBF & Kalbe Farma Tbk. \\
11 & PGAS & Perusahaan Gas Negara Tbk. \\
12 & SMGR & Semen Indonesia (Persero) Tbk. \\
13 & TLKM & Telekomunikasi Indonesia (Persero) Tbk. \\
14 & UNTR & United Tractors Tbk. \\
15 & UNVR & Unilever Indonesia Tbk. \\
\hline
\end{tabular}

Sumber : www.idx.co.id

Metode pengumpulan data yang digunakan dalam penelitian ini adalah metode observasi non partisipan yaitu observasi yang dilakukan tanpa melibatkan diri dan hanya sebagai pengamat independen. Dalam metode ini, data diperoleh melalui pengumpulan data dengan cara melakukan pengamatan dan mencatat dengan cara mengakses Bursa Efek Indonesia (BEI). Data tersebut diperoleh dalam bentuk daftar harga saham penutupan (closing price) IDX30, IHSG dan laporan historis lainya di BEI.

Penelitian ini menggunakan statistik deskriptif untuk variable-variabel yang digunakan dalam penelitian ini disajikan dalam bentuk tabel statistika deskriptif berupa nilai rata- rata (mean), nilai maksimum, nilai minimum, dan nilai deviasi standar. Penelitian ini menggunakan teknik analisis data uji one sample t-test untuk mengetahui apakah pengumuman penurunan harga BBM menciptakan Abnormal return yang signifikan. Uji ini untuk mengukur tingkat signifikansi dengan tingkat kesalahan $\alpha=5 \%$. Cara pengolahannya dengan menggunakan program SPSS (Statistic Produk Service Solution) dan Microsoft Excel.

Return merupakan hasil yang diperoleh dari investasi, return dapat berupa return realisasi yang sudah terjadi atau return ekspektasi yang belum terjadi tetapi diharapkan akan terjadi masa mendatang.

Abnormal return merupakan selisih antara Actual return dengan expected return. Actual return adalah selisih antara harga sekarang dengan harga sebelumnya secara relatif, kemudian dihitung besarnya rata-rata Abnormal return saham sebelum dan sesudah peristiwa pengumuman penurunan harga bahan bakar minyak (BBM). Penelitian ini menggunakan metode market adjusted model untuk mengestimasi expected return. Model ini dipilih karena menurut Hartono (2017:679) market adjusted model menganggap bahwa penduga yang terbaik untuk mengestimasi return suatu sekuritas adalah indeks pasar pada saat tersebut. Dengan menggunakan model ini, maka tidak perlu menggunakan periode estimasi untuk membentuk model estimasi, karena return sekuritas yang diestimasi adalah sama dengan return indeks pasar. 
Menghitung actual return (return sesungguhnya), (Hartono, 2017:668):

$R_{i t}=\frac{P_{t}-P_{t-1}}{P_{t-1}}$

Keterangan:

$$
\begin{aligned}
& \mathrm{R}_{\mathrm{it}}=\text { Return saham pada hari ke-t. } \\
& \mathrm{P}_{\mathrm{t}} \quad=\text { harga saham pada hari ke-t } \\
& \mathrm{P}_{\mathrm{t}-1} \quad=\text { harga saham sebelumnya }
\end{aligned}
$$

Menghitung expected return dengan menggunakan model sesuaian pasar (market adjusted model) (Hartono,2017:679):

$E\left[R_{i t}\right]=R_{M t}$

Keterangan:

$$
\begin{array}{cl}
\begin{array}{c}
\mathrm{E}[\mathrm{Rit}] \\
\mathrm{Rit}
\end{array} & \begin{array}{l}
=\text { Return ekspektasi sekuritas ke-I pada periode peristiwa ke-t. } \\
= \\
\\
\text { periode peristiwa ke-t. }
\end{array} \\
R_{M t}=\frac{I H S G_{t}-I H S G_{t-1}}{I H S G_{t-1}} & \text { Return realisasian yang terjadi untuk sekuritas ke-i pada }
\end{array}
$$

Keterangan:

$R_{M t} \quad=$ Return indeks pasar pada periode peristiwa ke-t.

$\mathrm{IHSG}_{\mathrm{t}} \quad=$ Indeks harga saham gabungan pada periode tertentu pada periode peristiwa ke-t.

$\mathrm{IHSG}_{\mathrm{t}-1}=$ Indeks harga saham gabungan pada periode sebelumnya

Menghitung abnormal return untuk masing-masing emiten (Hartono, 2017:668):

$\mathrm{RTNi}, \mathrm{t}=\mathrm{Ri}, \mathrm{t}-\mathrm{E}[\mathrm{Ri}, \mathrm{t}]$.

Keterangan:

$\mathrm{RTNi}, \mathrm{t}=$ Abnormal return untuk sekuritas ke-i pada periode peristiwa ke-t.

$\mathrm{Ri}, \mathrm{t}=$ Return realisasian yang terjadi untuk sekuritas ke-i pada periode peristiwa ke-t.

$\mathrm{E}[\mathrm{Ri}, \mathrm{t}]=$ Return ekspektasi sekuritas ke-i pada periode peristiwake-t.

Menghitung rata-rata abnormal return (Hartono,2017:680):

$\operatorname{RRTN}_{t}=\frac{\sum_{i=1}^{k} R T N_{i t}}{k}$

Keterangan:

$\mathrm{RRTNt}=$ Rata-rata abnormal return pada harike-t.

RTNit = Abnormal return untuk sekuritas ke-i pada hari ke-t.

$\mathrm{k}=$ Jumlah sekuritas peristiwa yang terpengaruh oleh pengumuman.

Menghitung Standar Kesalahan Estimasi ( Hartono,2017:701):

$K S E_{t} \sqrt{\frac{\sum_{i=1}^{k}\left(\mathrm{RTN}_{\mathrm{it}}-\mathrm{RRTN \textrm {t }}\right)^{2}}{k-1}} \cdot \frac{1}{\sqrt{k}}$.

Keterangan: 
Ni Komang Mega Sri Utami, Dampak Pengumuman Penurunan...

KSEt = Kesalahan standar estimasi untuk hari ke-t di periode peristiwa.

RTNit = Return tidak normal sekuritas ke-i untuk hari ke-t di periode peristiwa.

RRTNt = Rata-rata return tidak normal sekuritas untuk hari ke-t di periode peristiwa.

$\mathrm{k} \quad=$ Jumlah sekuritas.

Menghitung signifikansi abnormal return yang terjadi dengan pengujian statistik t-test, (Hartono,2017:686):

$$
t=\frac{\beta}{s} .
$$

Keterangan:

$$
\begin{array}{ll}
\mathrm{t} & =\mathrm{t} \text {-hitung } \\
\mathrm{S} & =\text { Kesalahan Standar Estimasi } \\
\beta & =\text { Rata-rata abnormal return harian }
\end{array}
$$

\section{HASIL DAN PEMBAHASAN}

Berdasarkan Tabel 2, terlihat bahwa selama jendela peristiwa terdapat Actual return yang bernilai positif, bernilai nol dan bernilai negatif. Actual return bernilai positif mengindikasikan adanya peningkatan harga saham $\mathrm{ke}_{\mathrm{t}}$ dari harga saham ke $\mathrm{t}_{\mathrm{t}-1}$.Actual return bernilai negatif mengindikasikan bahwa harga saham $\mathrm{ke}_{\mathrm{t}}$ lebih rendah dari harga saham $\mathrm{ke}_{\mathrm{t}-1}$ Actual return yang bernilai nol berarti harga saham ke $\mathrm{t}_{\mathrm{t}}$ sama dengan $\mathrm{ke}_{\mathrm{t}-1}$.

Tabel 2.

Rekapitulasi Komposisi Hasil Perhitungan Actual Return pada Periode Peristiwa

\begin{tabular}{ccccc}
\hline \multirow{2}{*}{ Hari ke-t } & \multicolumn{3}{c}{ Actual Return } & Rata-rata Actual \\
\cline { 2 - 4 } return
\end{tabular}

Pada pengumuman penurunan harga BBM tanggal 31 januari 2020 sebanyak 57 sebesar $34.55 \%$ saham memiliki nilai Actual return negatif, 16 sebesar 9.70\% saham memiliki nilai Actual return sebesar nol, 92 sebesar 55.76\% saham memiliki nilai Actual return positif. 


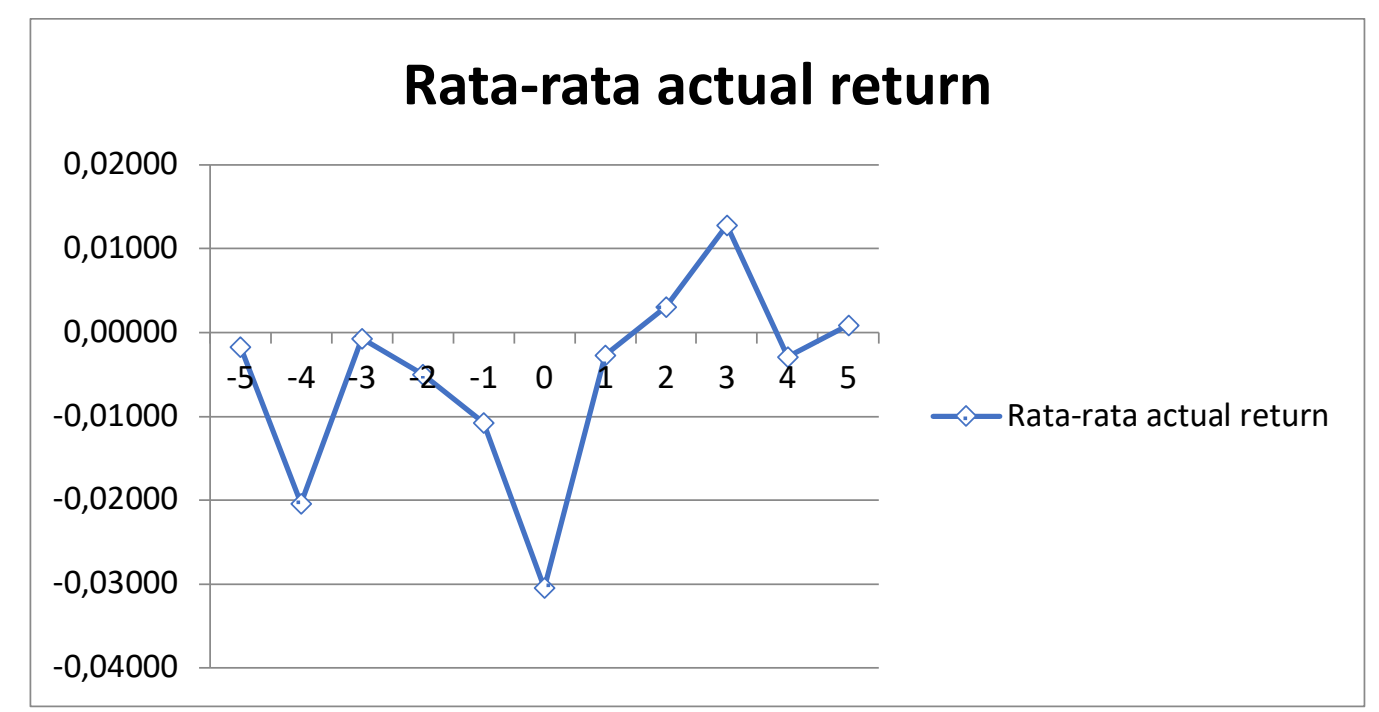

\section{Gambar 2. Pergerakan Rata-Rata Actual Return Periode Peristiwa}

Sumber : Data diolah, 2020

Gambar 2. menunjukkan bahwa pergerakan rata-rata Actual return mengalami penurunan tajam dari $\mathrm{t}_{-3}$ sampai $\mathrm{t}_{0}$, kemudian mengalami peningkatan secara perlahan pada $t_{+1}$ sampai $t_{+3}$ dan mengalami penurunan kembali di $t_{4}$ hingga akhirnya mengalami kenaikan kembali pada $t+5$.

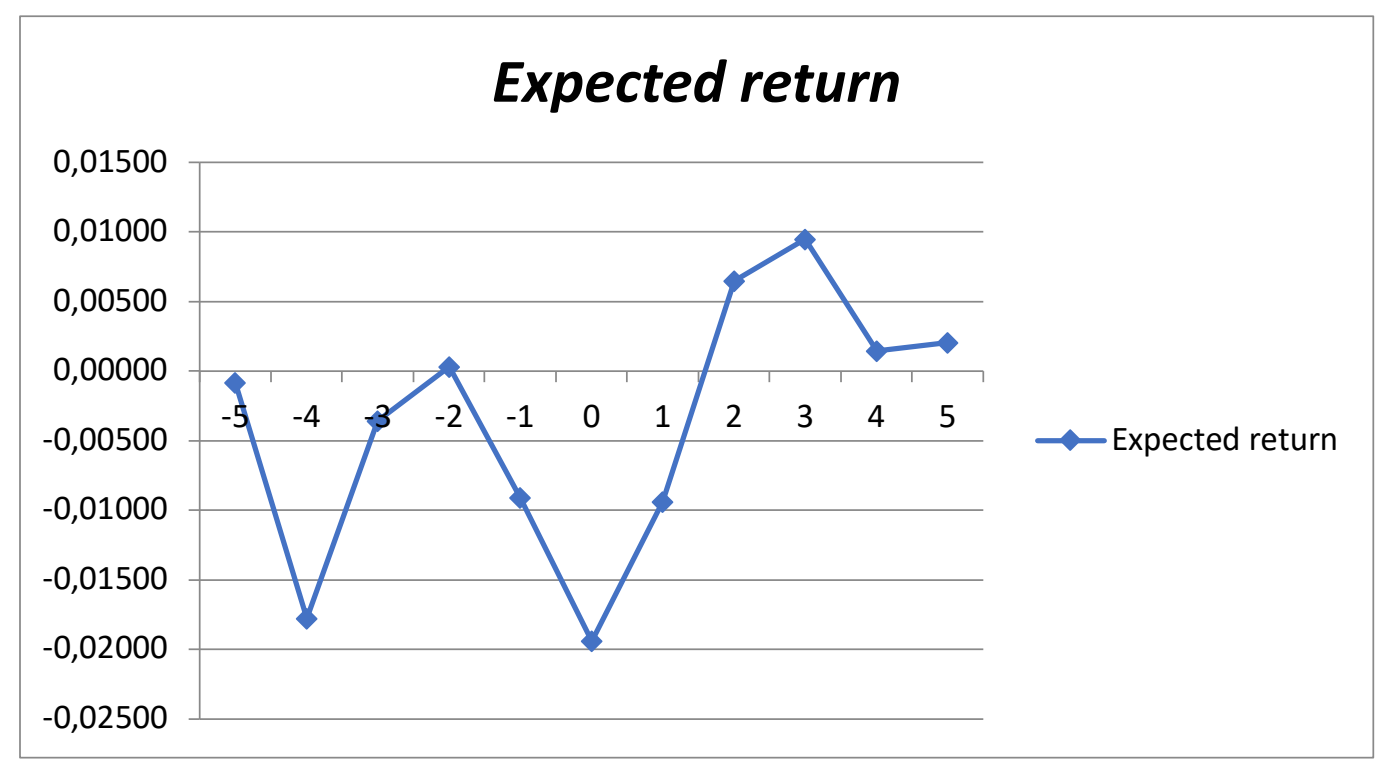

\section{Gambar 3. Pergerakan Expected Return Periode Peristiwa}

Sumber : Data diolah, 2020

Expected return dihitung menggunakan pendekatan market-adjusted model, sehingga nilai expected return untuk masing-masing sekuritas sama dengan return indeks pasar. Gambar 3. menunjukkan bahwa pergerakan expected return peristiwa pengumuman penurunan harga BBM, expected return juga menunjukkan pergerakan yang berfluktuatif. Expected return mengalami penurunan tajam dari $t_{-2}$ sampai $t_{0}$, kemudian mengalami peningkatan tajam dari 
$t_{+1}$ sampai $t_{+3}$ dan mengalami penurunan kembali di $t_{4}$ dan mengalami kenaikan kembali pada $t_{+5}$.

Tabel 3.

Rekapitulasi Komposisi Hasil Perhitungan Abnormal Return pada Periode Peristiwa

\begin{tabular}{cccc}
\hline \multirow{2}{*}{ Hari ke-t } & \multicolumn{2}{c}{ Abnormal Return } & $\begin{array}{c}\text { Rata-rata Abnormal } \\
\text { return }\end{array}$ \\
\cline { 2 - 3 } & Positif & Negatif & -0.00084 \\
$\mathbf{- 5}$ & 8 & 7 & -0.00260 \\
$\mathbf{- 4}$ & 7 & 8 & 0.00289 \\
$\mathbf{- 3}$ & 10 & 5 & -0.00527 \\
$\mathbf{- 2}$ & 5 & 10 & -0.00165 \\
$\mathbf{- 1}$ & 9 & 6 & -0.01107 \\
$\mathbf{0}$ & 5 & 10 & 0.00668 \\
$\mathbf{1}$ & 10 & 5 & -0.00338 \\
$\mathbf{2}$ & 7 & 8 & 0.00332 \\
$\mathbf{3}$ & 8 & 7 & -0.00430 \\
$\mathbf{4}$ & 5 & 10 & -0.00117 \\
$\mathbf{5}$ & 7 & 8 & 165 \\
\cline { 1 - 2 } Jumlah & 81 & 84 & $100.00 \%$ \\
\hline Persentase & $49.09 \%$ & $50.91 \%$ & \\
\hline
\end{tabular}

Sumber : Data diolah, 2020

Pada pengumuman penurunan harga BBM tanggal 31 januari 2020 sebanyak 81 sebesar $49.09 \%$ saham memiliki nilai Abnormal return negatif dan 84 sebesar 50.91\% saham memiliki nilai Abnormal return positif.

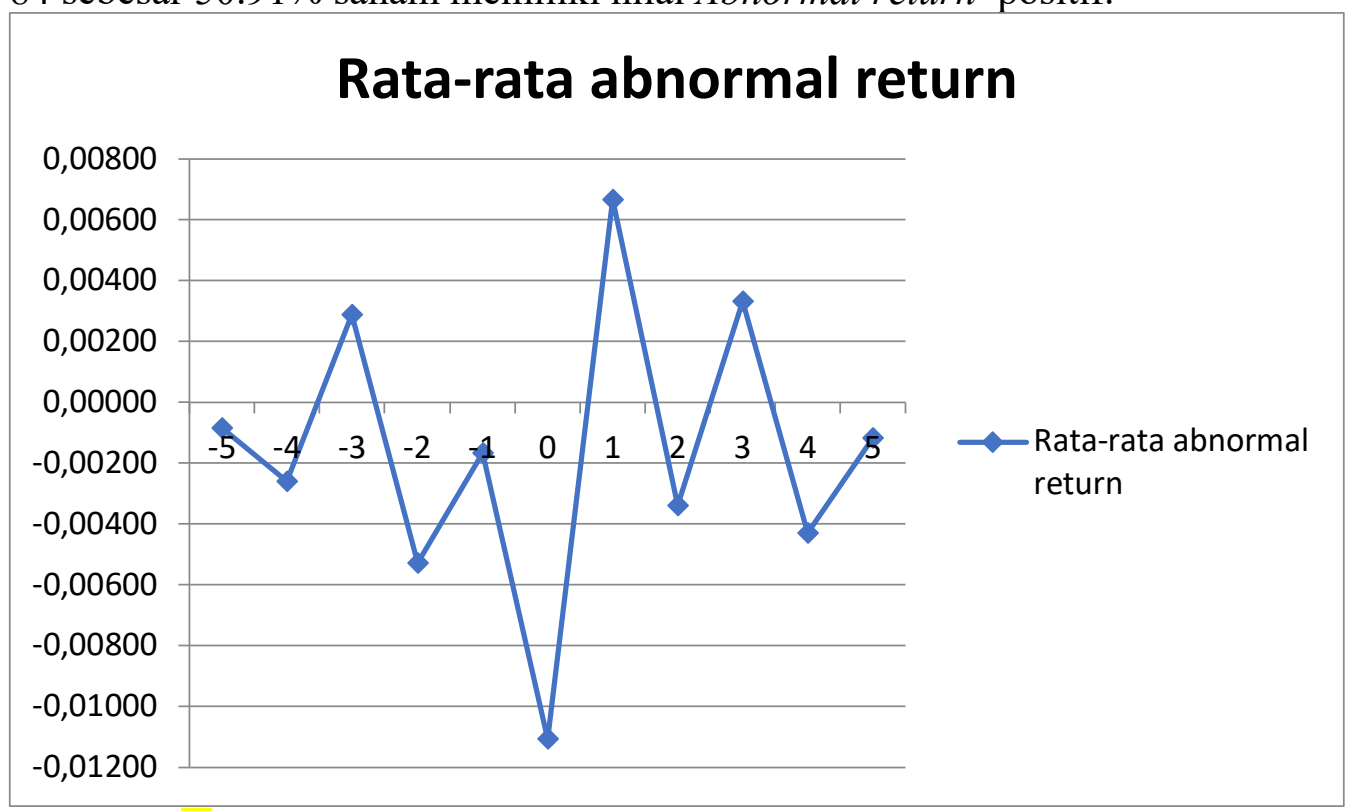

Gambar 4. Pergerakan Rata-Rata Abnormal Return Periode Peristiwa Sumber : Data diolah, 2020 
Gambar 4. menunjukkan bahwa pergerakan rata-rata Abnormal return mengalami penurunan tajam dari $\mathrm{t}_{-1}$ sampai $\mathrm{t}_{0}$, kemudian mengalami peningkatan tajam pada $t_{+1}$ dan mengalami penurunan kembali di $t_{+2}$ dan $t_{+4}$ hingga akhirnya mengalami kenaikan kembali pada $t_{+5}$.

Pengujian hipotesis dalam penelitian ini menggunakan uji one sample t-test, yaitu menguji apakah terdapat Abnormal return positif yang signifikan sebelum, saat dan sesudah pengumuman penurunan harga BBM tanggal 31 januari 2020 pada saham IDX30 di Bursa Efek Indonesia. Pengujian terhadap Abnormal return di sekitar periode pengumuman penurunan harga BBM pada saham IDX30 dianalisis dengan menggunakan uji statistik One sample t-test dengan bantuan program SPSS dengan tujuan untuk menguji signifikansi Abnormal return di sekitar periode pengumuman penurunan harga BBM.

Berdasarkan Tabel 4, terlihat bahwa selama jendela peristiwa terdapat Abnormal return yang bernilai positif dan bernilai negatif. Abnormal return bernilai positif berarti bahwa Actual return dari saham selama periode peristiwa lebih besar nilainya dibandingkan dengan expected return yang diprediksi oleh para investor, sebaliknya Abnormal return negatif berarti bahwa Actual return lebih kecil nilainya daripada expected return.

Tabel 4.

Statistik Deskriptif Abnormal Return

\begin{tabular}{rrrrrr}
\hline \multicolumn{5}{c}{ Descriptive Statistics } \\
\hline $\mathrm{t}-5$ & 15 & -0.02141 & 0.02011 & -0.0008413 & 0.01227013 \\
$\mathrm{t}-4$ & 15 & -0.04383 & 0.02999 & -0.0026040 & 0.01748020 \\
$\mathrm{t}-3$ & 15 & -0.00957 & 0.02676 & 0.0028927 & 0.00968009 \\
$\mathrm{t}-2$ & 15 & -0.03180 & 0.01797 & -0.0052647 & 0.01544350 \\
$\mathrm{t}-1$ & 15 & -0.02459 & 0.01185 & -0.0016533 & 0.01054221 \\
0 & 15 & -0.03670 & 0.02075 & -0.0110693 & 0.01832826 \\
$\mathrm{t}+1$ & 15 & -0.00976 & 0.03738 & 0.0066780 & 0.01326271 \\
$\mathrm{t}+2$ & 15 & -0.11237 & 0.03025 & -0.0033833 & 0.03315397 \\
$\mathrm{t}+3$ & 15 & -0.03909 & 0.05135 & 0.0033213 & 0.02102246 \\
$\mathrm{t}+4$ & 15 & -0.04061 & 0.02906 & -0.0042967 & 0.01610180 \\
$\mathrm{t}+5$ & 15 & -0.01747 & 0.01740 & -0.0011713 & 0.00921214 \\
\hline
\end{tabular}

Sumber : Data diolah, 2020

Tabel 4, menjelaskan nilai maximum, minimum, rata-rata serta standar deviasi. Pada t-5 nilai minimum diperoleh perusahaan PT Kalbe Farma Tbk sebesar -0.02141, dan nilai maximum diperoleh oleh perusahaan PT Bank Mandiri 
Tbk sebesar 0.02011. Rata-rata Abnormal return t-5 bernilai negatif sebesar 0.0008413 dan standar deviasi sebesar 0.01227013 .

Pada t-4 nilai minimum diperoleh perusahaan PT Adaro Energy Tbk sebesar -0.04383 , dan nilai maximum diperoleh oleh perusahaan PT Unilever Indonesia Tbk sebesar 0.02999. Rata-rata Abnormal return t-4 bernilai positif sebesar-0.0026040 dan standar deviasi sebesar 0.01748020 .

Pada t-3 nilai minimum diperoleh perusahaan PT Kalbe Farma Tbk sebesar -0.00957, dan nilai maximum diperoleh oleh perusahaan PT Adaro Energy Tbk sebesar 0.02676. Rata-rata Abnormal return t-3 bernilai positif sebesar 0.0028927 dan standar deviasi sebesar 0.00968009 .

Pada t-2 nilai minimum diperoleh perusahaan PT Semen Indonesia Tbk sebesar -0.03180, dan nilai maximum diperoleh oleh perusahaan PT Telekomunikasi Indonesia Tbk sebesar 0.01797. Rata-rata Abnormal return t-2 bernilai negatif sebesar -0.0052647 dan standar deviasi sebesar 0.01544350 .

Pada t-1 nilai minimum diperoleh perusahaan PT Indocement Tunggal Prakarsa Tbk sebesar -0.02459 , dan nilai maximum diperoleh oleh perusahaan PT Perusahaan Gas Negara Tbk sebesar 0.01185. Rata-rata Abnormal return t-1 bernilai negatif sebesar -0.0016533dan standar deviasi sebesar 0.01054221 .

Pada Hari $\mathrm{H}$ nilai minimum diperoleh perusahaan PT Kalbe Farma Tbk sebesar -0.03670, dan nilai maximum diperoleh oleh perusahaan PT Gudang Garam Tbk sebesar 0.02075. Rata-rata Abnormal return Hari H bernilai positif sebesar-0.0110693 dan standar deviasi sebesar 0.01832826 .

Pada $\mathrm{t}+1$ nilai minimum diperoleh perusahaan Indofood Sukses Makmur Tbk sebesar -0.00976, dan nilai maximum diperoleh oleh perusahaan PT Kalbe Farma Tbk sebesar 0.03738. Rata-rata Abnormal return $\mathrm{t}+1$ bernilai positif sebesar 0.0066780dan standar deviasi sebesar 0.01326271 .

Pada $\mathrm{t}+2$ nilai minimum diperoleh perusahaan PT Perusahaan Gas Negara Tbk sebesar -0.11237 , dan nilai maximum diperoleh oleh perusahaan PT Adaro Energy Tbk sebesar 0.03025. Rata-rata Abnormal return $\mathrm{t}+2$ bernilai negatif sebesar -0.0033833 dan standar deviasi sebesar 0.03315397 .

Pada $\mathrm{t}+3$ nilai minimum diperoleh perusahaan PT Perusahaan Gas Negara Tbk sebesar -0.03909, dan nilai maximum diperoleh oleh perusahaan PT Indocement Tunggal Prakarsa Tbk sebesar 0.05135. Rata-rata Abnormal return $\mathrm{t}+3$ bernilai positif sebesar 0.0033213 dan standar deviasi sebesar 0.02102246 .

Pada $\mathrm{t}+4$ nilai minimum diperoleh perusahaan PT Indocement Tunggal Prakarsa Tbk sebesar -0.04061, dan nilai maximum diperoleh oleh perusahaan PT Perusahaan Gas Negara Tbk sebesar 0.02906. Rata-rata Abnormal return $\quad \mathrm{t}+4$ bernilai negatif sebesar -0.0042967 dan standar deviasi sebesar 0.01610180 .

Pada $\mathrm{t}+5$ nilai minimum diperoleh perusahaan PT Astra International Tbk sebesar -0.01747, dan nilai maximum diperoleh oleh perusahaan Indofood Sukses Makmur Tbk sebesar 0.01740 . Rata-rata Abnormal return $\quad \mathrm{t}+5$ bernilai negatif sebesar-0.0011713 dan standar deviasi sebesar 0.00921214.

Hasil dari pengolahan menggunakan program SPSS terhadap Abnormal return saham dengan alat uji one sample t-test pada pengumuman penurunan harga BBM tanggal 31 Januari 2020, selama periode peristiwa memperlihatkan 
tidak ada Abnormal return yang signifikan didapat oleh investor. Tidak terdapatnya Abnormal return yang signifikan tersebut menunjukkan tidak adanya reaksi yang diberikan pasar modal terhadap pengumuman penurunan harga BBM. Hasil dari analisis SPSS one sample t-test terhadap Abnormal return pada pengumuman penurunan harga BBM tanggal 31 Januari 2020 secara lengkap.

Tabel 5.

Hasil Pengujian Abnormal Return One Sample t-test Peristiwa Pengumuman Penurunan Harga BBM

\begin{tabular}{cccc} 
No & Hari ke-t & $\mathrm{t}$ & Sig. (2-tailed) \\
\hline 1 & & -0.266 & 0.794 \\
2 & $\mathrm{t}-5$ & -0.577 & 0.573 \\
3 & $\mathrm{t}-4$ & 1.157 & 0.266 \\
4 & $\mathrm{t}-3$ & -1.320 & 0.208 \\
5 & $\mathrm{t}-2$ & -0.607 & 0.553 \\
6 & $\mathrm{t}-1$ & -2.339 & 0.035 \\
7 & 0 & 1.950 & 0.071 \\
8 & $\mathrm{t}+1$ & -0.395 & 0.699 \\
9 & $\mathrm{t}+2$ & 0.612 & 0.550 \\
10 & $\mathrm{t}+3$ & -1.033 & 0.319 \\
11 & $\mathrm{t}+4$ & -0.492 & 0.630 \\
\hline
\end{tabular}

Sumber : Data diolah, 2020

Abnormal return pada lima hari sebelum peristiwa hingga lima hari setelah peristiwa ditunjukkan oleh Tabel 5, hasil analisis one sample t-test Abnormal return saham pada pengumuman penurunan harga BBM tanggal 31 Januari 2020 memperlihatkan tidak adanya ahnormal return positif yang signifikan pada tingkat 5\%. Abnormal return pada keseluruhan peristiwa pengumuman penurunan harga BBM didominasi oleh Abnormal return negatif. Abnormal return positif tidak signifikan di pengumuman penurunan harga BBM tanggal 31 Januari 2020 terjadi pada t-3 dengan t-hitung sebesar 1.157 dengan signifikansi sebesar $0.266>0.05$, $\mathrm{t}+1$ dengan t-hitung sebesar 1.950 dengan signifikansi sebesar $0.071>0.05$ dan $\mathrm{t}+3$ dengan t-hitung sebesar 0.612 dengan signifikansi sebesar $0.550>0.05$ hasil pengujian tidak signifikan secara statistic.

Tabel 6.

Hasil Pengujian Rata-rata Abnormal Return One Sample t-test Peristiwa Pengumuman Penurunan Harga BBM

One-Sample Test

Test Value $=0$

\begin{tabular}{|c|c|c|c|c|c|c|}
\hline & \multirow[b]{2}{*}{$\mathrm{t}$} & \multirow[b]{2}{*}{ df } & \multirow[b]{2}{*}{ Sig. (2-tailed) } & \multirow{2}{*}{$\begin{array}{c}\text { Mean } \\
\text { Difference }\end{array}$} & \multicolumn{2}{|c|}{$\begin{array}{l}\text { 95\% Confidence Interval of the } \\
\text { Difference }\end{array}$} \\
\hline & & & & & Lower & Upper \\
\hline$\overline{A A R}$ & -1.097 & 10 & .298 & -.00158091 & -.0047908 & .0016290 \\
\hline
\end{tabular}


Tabel 6, memperlihatkan bahwa tidak terdapat rata-rata Abnormal return positif dan signifikan selama periode pengumuman penurunan harga BBM. Ratarata Abnormal return peristiwa pengumuman penurunan harga BBM tanggal 31 Januari 2020 memiliki t-hitung sebesar -1.097 dengan signifikansi sebesar $0.298>0.05$.

Berdasarkan Pengujian statistik terhadap Abnormal return dengan alat uji one sample t-test dengan tingkat signifikansi 5 persen diperoleh nilai signifikansi sebesar 0.298>0.05 yang memperlihatkan bahwa hasil tersebut tidak signifikan pada pengumuman penurunan harga BBM tanggal 31 Januari 2020. Berdasarkan hasil pengujian tersebut, maka Hipotesis dalam penelitian ini ditolak, yaitu tidak terdapat rata-rata Abnormal return positif yang signifikan sebelum, saat, dan sesudah pengumuman penurunan harga BBM tanggal 31 Januari 2020 pada saham IDX30 di Bursa Efek Indonesia.

Abnormal return pada pengumuman penurunan harga BBM tanggal 31 Januari 2020 memberikan hasil yang tidak signifikan terhadap Abnormal return yang diterima investor. Pengumuman penurunan harga BBM tanggal 31 Januari 2020 menghasilkan angka positif hanya pada $\mathrm{t}-3, \mathrm{t}+1$ dan $\mathrm{t}+3$ setelah peristiwa. Dalam penelitian ini kebocoran informasi terjadi karena pengumuman penurunan harga BBM merupakan informasi publik yang telah direncanakan sebelumnya, akan tetapi informasi tersebut direspon investor sebagai informasi yang tidak memiliki dampak ekonomi, sehingga investor tidak menggunakan informasi tersebut sebagai dasar untuk mendapatkan Abnormal return.

Reaksi pasar yang terjadi berdasarkan pengujian ini terjadi dengan lambat dibuktikan dengan tidak adanya Abnormal return yang signifikan pada saat dan setelah peristiwa pengumuman penurunan harga BBM. Secara statistik selama periode peristiwa pengumuman penurunan harga BBM tidak diperoleh Abnormal return yang signifikan pada penelitian ini yang berarti bahwa pasar tidak merespon peristiwa penurunan harga BBM dikarenakan investor terlebih dahulu melakukan analisis melalui media massa, media cetak dan media elektronik sebelum akhirnya memutuskan berinvestasi. Peristiwa seperti ini akan sering terjadi menyusul perubahan harga minyak dunia sehingga investor sadar bahwa penurunan harga BBM tidak akan terlalu berdampak pada perekonomian. Dengan tidak adanya investor yang mendapatkan Abnormal return menandakan pasar mendukung efisiensi pasar dalam bentuk setengah kuat.

Hasil penelitian dari peristiwa Penurunan Harga BBM ini menunjukkan bahwa tidak adanya reaksi pasar dan dampaknya tidak signifikan terhadap Abnormal return saham pada perusahaan yang terdaftar pada IDX30. Hasil penelitian ini tidak mendukung mark et efficient theory karena informasi yang dipublikasikan tidak menimbulkan reaksi yang signifikan pada pasar. Hasil penelitian menunjukkan bahwa pasar ketika Peristiwa Penurunan Harga BBM dalam bentuk setengah kuat dilihat dari cepatnya respon pasar terhadap peristiwa, dimana setelah dikeluarkannya pengumuman Penurunan Harga BBM yang langsung direspon oleh pasar terlihat dari fluktuasi harga yang terjadi dan perubahan Abnormal return setelah pengumuman Penurunan Harga BBM. 
Hasil dari penelitian ini memberikan implikasi praktis bagi investor bahwa ketika Peristiwa Penurunan Harga BBM sebaiknya investor memilah dan menganalisis informasi yang relevan untuk dijadikan pertimbangan dalam membuat keputusan investasi di masa mendatang. Investor selain berbekal informasi yang relevan juga harus memperhitungkan risk dan return yang didapat ketika akan melakukan investasi saat Peristiwa Penurunan Harga BBM.

\section{SIMPULAN}

Berdasarkan hasil uji one sample t-test memperoleh nilai signifikansi sebesar $0.298>0.05$, yang dimana nilai sig. (2-tailed) $>0,05$ maka dapat disimpulkan tidak terdapat Abnormal return positif yang signifikan sebelum, saat dan sesudah peristiwa yang menunjukkan bahwa tidak terjadi reaksi pasar disekitaran periode peristiwa pengumuman penurunan harga BBM. Tidak satupun investor yang mendapatkan Abnormal return, yang menunjukkan bahwa pasar modal dalam keadaan efisien bentuk setengah kuat. Hasil yang tidak signifikan dalam penelitian ini disebabkan karena isu seputaran harga BBM akan mengikuti harga minyak dunia sudah beredar luas sebelumnya, sehingga pelaku pasar dapat menganalisa dampak penurunan harga BBM terhadap perekonomian nasional sebelum mengambil keputusan berinvestasi.

Penelitian ini diharapkan dapat dimanfaatkan oleh investor sebagai bahan pertimbangan dalam pengambilan keputusan maupun tanggapan atas informasi yang dipublikasikan, Sebelum berinvestasi sebaiknya investor melakukan analisis terlebih dahulu. Diharapkan peneliti selanjutnya akan menggunakan metode penghitungan Abnormal return yang berbeda dari penelitian sebelumnya, dan menambahkan periode peristiwa sebagai dasar penelitian mereka.

\section{REFERENSI}

Agustina, L., Gunawan, Y., \& Chandra, W. (2018). The Impact of Tax Amnesty Announcement towards Share Performance and Market Reaction in Indonesia. Accounting and Finance Research, 7(2), 39. https://doi.org/10.5430/afr.v7n2p39

Andarini, D., \& Raharjo, T. (2016). Analisis Reaksi Pasar Modal Terhadap Perubahan Harga Bbm (Event Study Kenaikan dan Penurunan Harga BBM pada Perusahaan Food and Beverages yang terdaftar di Bursa Efek Indonesia). Jurnal Ilmiah Mahasiswa Fakultas Ekonomi dan Bisnis Universitas Brawijaya,

$3(2)$. https://jimfeb.ub.ac.id/index.php/jimfeb/article/view/1840

Anggraini, F. (2017). Analisis Reaksi Pasar Atas Peristiwa Pengumuman Kebijakan Holding BUMN Pertambangan. Skripsi.

Anisah, N., Pujiati, L., Anisah, N., Pujiati, L., \& Widiarti, D. S. (2017). Pengaruh 
Perubahan Harga Bahan Bakar Minyak Terhadap Investasi Saham Perusahaan Transportasi Darat. 12(1), 9-20.

Anita, D., \& Veronica, S. L. (2016). Analisis Reaksi Pasar Modal Dalam Perubahan Harga Bahan Bakar Minyak (Bbm) Masa Pemerintahan Susilo Bambang Yudhoyono (Sby) Pada Sektor Transportasi Menggunakan Metode Event Study. Kurs, 1(2), 237-256.

Ardani, N. M. (2019). Studi Komparatif Reaksi Pasar Sebelum Dan Sesudah Kenaikan Harga Bbm Atas Saham Lq-45 Di Bei (Even Study Pada Peristiwa Kenaikan Bbm Tanggal 5 Januari 2017). Jurnal Pendidikan Ekonomi Undiksha, 10(2), 616. https://doi.org/10.23887/jjpe.v10i2.20142

Ardiana, Agus. (2016). Investasi Saham. Hibah Buku Ajar Jurusan Akuntansi FEB Unud.

Asmas, D. (2018). Pengaruh Pengumuman Perubahan Harga BBM terhadap Abnormal Return dan Trading Volume Activity pada PerusahaanPeruasahaan yang Tergabung dalam Kelompok LQ 45 Dibursa Efek Indonesia periode 2015-2016. Jurnal Ilmiah Universitas Batanghari Jambi, 18(3), 659. https://doi.org/10.33087/jiubj.v18i3.534

Chandra, T. (2013). the Impact of Fuel Price Increase on Stock Price in Indonesia Stock Exchange. Journal of Economics, Business, and Accountancy | Ventura, 16(3), 385. https://doi.org/10.14414/jebav.v16i3.219

Choriliyah, S., Sutanto, H. A., Hidayat, D. S. (2016). Reaksi Pasar Modal Terhadap Penurunan Harga Bahan Bakar Minyak (BBM) Atas Saham Sektor Industri Transportasi Di Bursa Efek Indo Nesia. Journal Of Economic Education, 5(1), 1-10. http://journal.unnes.ac.id/sju/index.php/jeec

Dananjaya, I. B. G. (2020). Market reaction before and after stipulation of presidential regulation point 55 in 2019. International Research Journal of Management, IT and Social Sciences, 7(1), 235-241. https://doi.org/10.21744/irjmis.v7n1.841

Dedunu, H. H. (2018). Impact of Dividend Announcement on Share Price: Evidence from Colombo Stock Exchange. International Journal of Management Sciences and Business Research, 7(12), 1-7.

Dinar, A. H., \& Kiryanto. (2015). Analisis Dampak Pemilu Presiden Jokowi Terhadap Return Saham (Studi Kasus Saham LQ-45 di Bursa Efek Indonesia). Jurnal Akuntansi Indonesia, 4(2), 97-108.

Dordi, T., \& Weber, O. (2019). The impact of divestment announcements on the share price of fossil fuel stocks. Sustainability (Switzerland), 11(11). 
https://doi.org/10.3390/su11113122

Febriyanti, S., \& Rahyuda, H. (2016). Pengaruh Pengumuman Perubahan Harga Bbm Awal Pemerintahan Jokowi-Jk Terhadap Reaksi Pasar Modal Indonesia. None, 5(2), 242901.

Gursida, H., \& Indrayono, Y. (2019). Understanding capital market responses to government economic policy announcements: An event study on Indonesia's Economic Policy Package. Management Science Letters, 9(11), 1887-1900. https://doi.org/10.5267/j.msl.2019.6.004

Handoko, Liza. (2016). Analisis Reaksi Pasar Terhadap Pengumuman Dividen Perusahaan LQ45. Jurnal Riset Bisnis dan Manajemen, 4 (3), 269-276.

Hartono, Jogiyanto. (2017). Teori Portofolio dan Analisis Investasi. Edisi Kesebelas. Yogyakarta: BPFE-YOGYAKARTA

Kharisma, F., \& Jogiyanto (2016) Events Study: The Effect Of Oil Price Changes In Jokowi's Government To Share Price On Manufacturing Companies Listed In Indonesia Stock Exchange. 4th Asian Academic Society International Conference (AASIC).

K, P., \& P, K. (2018). The impact of dividend announcement on stock prices in Muscat securities market, Muscat. Open Access Journal of Science, 2(6), 409-417. https://doi.org/10.15406/oajs.2018.02.00106

Liogu, S. J., \& Saerang, I. S. (2015). Capital Market Reactions Toward The Announcement Of Increasing Fuel Prices Over LQ45 Stock On November 1st, 2014. Jurnal EMBA, 3(1), 1274-1282

Liu, Y., Dong, H., \& Failler, P. (2019). The oil market reactions to OPEC's announcements. Energies, 12(17), 1-15. https://doi.org/10.3390/en12173238

Nabila, F., \& Khairunnisa. (2015). Analisis Perbedaan Abnormal Return Sebelum dan Sesudah Peristiwa Politik (Pemilihan Umum Presiden) di Indonesia dan Singapura (Studi Kasus Terhadap Perusahaan Kelompok LQ45 Di BEI dan Strait Times Index di SGX). E-Proceeding of Management, 2(2), 1640-1648.

Ningsih, E. R., \& Cahyaningdyah, D. (2014). Reaksi pasar modal Indonesia terhadap pengumuman kenaikan harga BBM 22 Juni 2013. Management analysis journal, 1(3), 2252-6552.

Ngoc, D. B., \& Cuong, N. C. (2016). Dividend Announcement and Ex-Dividend Effects on Stock Return. International Journal of Economics and Finance, 8(7), 207. https://doi.org/10.5539/ijef.v8n7p207 
Nur, M., Nur, N., \& Agustin., H. (2019). The Effect Of Non-Subsidy Bbm On Stock Prices Increase In Manufacturing And Transportation Companies In Idx 2017-201. International Journal of Advanced Research in Management and Social Sciences, 8(12), 18-3.

Prasetyo, R., Kufepaksi, M., \& Hasnawati, S. (2020). Market Reaction Toward The Announcement of Domestic Market Obligation For Coal Price. International Journal of Economics and Management Studies, 7(2), 159163. https://doi.org/10.14445/23939125/ijems-v7i2p122

Putri, D. N., Sadalia, I., \& Irawati, N. (2020). Analysis of LQ45 Stock Market Index Reaction on Presidential Election 2019. 7(March), 463-472.

Rosita Dewi, G. A. S., Wirama, D. G., \& Rasmini, N. K. (2017). Reaksi Pasar Atas Pengumuman Paket Kebijakan Ekonomi X Tentang Daftar Negatif Investasi. Jurnal Ilmiah Akuntansi Dan Bisnis, 12(2), 104. https://doi.org/10.24843/jiab.2017.v12.i02.p05

Saputra, I. K. G., Purbawangsa, I. . A., \& Artini, S. G. L. (2017). Reaksi Pasar di Sekitar Peristiwa Kenaikan Harga BBM Pada Return Saham IDX30 di Bursa Efek Indonesia. E-Jurnal Ekonomi Dan Bisnis Universitas Udayana, 3(6), 963-990/ISSN : 2337-3067.

Syahputri, I., R. (2018). Pengaruh Suku Bunga, Inflasi, Nilai Tukar, Harga Emas Dunia Harga Minyak Dunia, Dan Indeks Dow Jones Terhadap Ihsg. Skripsi. Universitas Islam Negeri Sultan Syarif Kasim Riau. 